\section{Origin of Flints.}

Having paid some attention to the study of flints, both in England and Australia, I have read with interest the recent letters to NATURE on this question, and think that possibly some facts from this side of the globe may be worth noting. In the Cainozoic of South Australia and Victoria black flints occur which have the characteristic white coating of the English examples, and, in fact, are indistinguishable from them. They are found both in nodular and tabular form, and occur in lines parallel to the bedding. At Port Macdonell, South Australia, sheets of flint are found 2 in. or 3 in. thick, and, according to Tenison Woods, they are quarried and used for flagstones. These Cainozoic flints appear to be confined to the Miocene (Janjukian) beds, and are closely associated with the polyzoal limestone, a white, chalky deposit consisting of polyzoa and foraminifera.

The evidence of a microscopic examination of these flints goes to prove that the position held by Prof. G. A. J. Cole, that chalk flints represent a more or less complete replacement of the chalky ooze, is the only one tenable from the Australian point of view. The Australian flints are often crowded with the silicified remains of polyzoa, foraminifera, shell-fragments, and occasional sponge-spicules, the last merely included as a component of the ooze and not as selected material. During the formation of the flint the calcareous bodies are frequently dissolved, and only remnants are seen in some cases in the flint sections.

Another point in corroboration of Prof. Cole's contention (based on Liesegang's experiments) is the presence of an impervious bed underlying these Tertiary flint layers. This was pointed out long ago by Tenison Woods, who stated that well-sinkers in South Australia have observed that a layer of flint is always found immediately above the water-level. The factor of an impermeable laver inducing deposition of diffused silica is an important one, and is strongly supported in those instances where I have had an opportunity of observing it.

Fredk. Chapman.

National Museum, Melbourne, Victoria, August I7.

\section{Butterfly v. Wasp.}

I HAVE spent a good many hours iately in a Devonshire garden in which there was a border of massed mauve asters which was a great attraction to butterflies. The border measured $27 \mathrm{ft}$. by $2 \frac{1}{2} \mathrm{ft}$. only, but it was no unusual thing to see on it $r_{50}$ butterfliesPeacocks, Red Admirals, Tortoiseshell, Clouded Yellows - a very wonderful sight. The object of my letter is to describe to your readers two "scraps" which I witnessed between tortoiseshell butterflies and wasps, in each of which the butterfly was victorious. The method adopted was the same in each case. The butterfly sprang on to the back of the wasp, the head 0 f each being towards the tail of the other, and a furious rough-and-tumble took place some $6 \mathrm{ft}$. from the ground. The wasp was unable to use its sting, as the butterfly was on its back, and at the end of perhaps five seconds the butterfly, which had been buffeting the wasp with its wings, dropped to within a foot of the grass, relaxed the hold which it had exerted, and allowed its enemy to drop breathless and beaten on to the lawn.

Nature had taught the butterfly to adopt the same tactics (that of concentrating all its energy on the body of its adversary) which enabled G. Carpentier to win his fight with Bombardier Wells.

The Vicarage, Rochdale, Lancashire.

Arthur F. Clarke.

September 20

NO. $250 \mathrm{I}$, VOL. IOO
The Convolvulus Hawk-moth.

I REGRET that I must ask leave to correct a statement in my letter on this moth in NATURE of September 27. I find that it was not in the present year, but in I902, that the lady counted seven convolvulus hawkmoths flying about the tobacco plants in her garden.

Monreith, September 29.

Herbert Maxwell.

\section{THE ETHNOLOGY OF SCOTLAND.}

$\mathrm{T} T$ is as a fighting man that the Scot makes I his first appearance in written history; Tacitus depicts him as ruddy in colour, big in body, strong in limb, and Germanic in origin. In I866, when Huxley ${ }^{1}$ described the human remains discovered by $\mathrm{Mr}$. Samuel Laing in a long-cist cemetery at Keiss, Caithness, which the discoverer regarded as of early Neolithic date, but which are now rightly assigned to a much later period-an early phase of the Iron age-he had clearly reached a conclusion very similar to that of Tacitus :-

But the existence of a tall, long-headed, fair element becomes intelligible at once if we suppose that long before the well-known Norse and Danish invasions a stream of Scandinavians had set in to Scotland and Ireland and formed a large part of our primitive population (p. I34).

Huxley regarded the Scottish people, the Irish, the Norwegians, and the Swedes as possessing a common basal stock or type. Prof. Bryce, of the University of Glasgow, who has done so much to build up an accurate knowledge of the early inhabitants of the south-west of Scotland, accepts Huxley's hypothesis, and supposes that in early Neolithic times-before the long-barrow people, of Mediterranean origin, had reached Arran--Ireland, Scotland, and Scandinavia were already peopled by the same tall, fair, dolichocephalic stock. ${ }^{2}$ Dr. W. C. Mackenzie ${ }^{3}$ has also come to a somewhat similar conclusion from a study of the place-names of Scotland and Ireland, but supposes that the arrival of the Scandinavian or Germanic people occurred at a post-Neolithic date. The same hypothesis has also been sturdily advocated by Mr. John Munro."

Huxley preferred the term "Scandinavian" to "Germanic" when he wished to designate the tall, big-boned, fair, long-headed Scotsman, because he was well aware that this type prevails only in the western fourth of the modern German Empire. "Celt" and "Celtic," "Teuton" and "Teutonic," "German" and "Germanic," are terms which the modern anthropologist has had to abandon; all have been applied to the type of man Tacitus and Huxley had in mind, and also to physical types which are totally different. To the tall, long-headed Xanthochroi most modern anthropologists would apply the term "Nordic" in preference to "Scandinavian."

When we seek for evidence as to the time and manner in which the Nordic type reached Scot-

1 "Prehistoric Remains of Caithnesn." By Samuel Laing, M.P. (1866.) 2 "The Cairns of Arran." Proc. Soc. of Antic. of Scotland, rgoz, p. 75; Scottish Historical Review, 1905, p. 275., 4 "The Races of Ireland and Scotland." (Igr6.) 